\title{
Spatial distribution of surface ablation in the terminus of Rhonegletscher, Switzerland
}

\author{
Shin SUGIYAMA, ${ }^{1}$ Takeshi YOSHIZAWA, ${ }^{1,2}$ Matthias HUSS, ${ }^{3}$ Shun TSUTAKI, ${ }^{1,2}$ \\ Daisuke NISHIMURA ${ }^{1,2}$ \\ ${ }^{1}$ Institute of Low Temperature Science, Hokkaido University, Sapporo 060-0819, Japan \\ E-mail: sugishin@lowtem.hokudai.ac.jp \\ ${ }^{2}$ Graduate School of Environmental Science, Hokkaido University, Sapporo 060-0810, Japan \\ ${ }^{3}$ Department of Geosciences, University of Fribourg, CH-1700 Fribourg, Switzerland
}

\begin{abstract}
The spatial pattern of glacier surface melt was measured with a resolution of $20-100 \mathrm{~m}$ within a region extending $1 \mathbf{~ k m}$ up-glacier from the terminus of Rhonegletscher, Switzerland. The melt rate was monitored from 6 July to 6 September 2009 using 44 ablation stakes. We also measured the surface albedo near the stakes to investigate the importance of this parameter for the melt-rate distribution. The melt rate varied from 32.8 to $71.9 \mathrm{~mm}$ w.e. $\mathrm{d}^{-1}$ in the study area. Our measurements suggest that the spatial variation of the melt rate can be explained by (1) shading of the ice surface by neighbouring mountains, (2) surface albedo and (3) effects of microclimate (e.g. radiation from sidewalls) on the surface energy balance. The observed melt-rate distribution was compared to the results of a temperature-index melt model, which takes into account shading of direct solar illumination but not the other two effects. The model reproduces some important features of the field data, but its spatial variations are generally less than the measured values. Our study shows the importance of albedo and other local conditions in the accurate estimation of the small-scale melt-rate distribution.
\end{abstract}

\section{INTRODUCTION}

Glacier melt plays a key role in the hydrology of glacierized catchments. Run-off from mountain glaciers is an important resource for irrigation, hydropower generation and potable water in mountainous regions (e.g. Schaefli and others, 2007; Huss and others, 2008b). Accurate quantification of snow and ice melt on glaciers is therefore crucial for human activities. Melting is also important for the mass balance of mountain glaciers. Glaciers change their volume under the influence of climate conditions (e.g. Huss and others, 2009), and their mass loss significantly contributes to changes in global sea level (e.g. Meier and others, 2007). To predict future glacier evolution and its impact on human society, we must be able to estimate their melt rates from projected climate variables.

Glacier melt can be computed by energy-balance models (e.g. Klok and Oerlemans, 2002; Hock and Holmgren, 2005; Arnold and others, 2006). Solving the energy balance of the glacier surface involves the capture of complex processes, but such models require field observations that are difficult to acquire. Alternatively, glacier melt is often computed from air-temperature records by using temperature-index melt models (e.g. Braithwaite, 1995; Ohmura, 2001; Hock, 2003; Shea and others, 2009). Taking into account the expected spatial distribution of solar radiation improves computations of temporal and spatial glacier melt patterns (e.g. Hock, 1999). Such models have been tested against glacier discharge data, but their ability to reproduce small-scale spatial melt variation has not been well studied because high-resolution field data are lacking. Distributed temperature-index melt models do include some geometrical effects which determine the amount of potential solar radiation, such as shading by surrounding mountains and the angle of incidence of the solar beam on the glacier surface. Other key variables such as ice-surface albedo and wind-mediated sensible and latent heat exchanges are more difficult to take into account, but are equally important. Albedo is particularly important on mountain glaciers (e.g. Oerlemans and others, 2009), but its spatial and temporal variability is difficult to model; it must be measured on the glacier (e.g. Brock and others, 2000) or by using satellite data (e.g. Klok and others, 2003).

To study spatial variations in glacier surface melt on the scale of tens of metres in the crucial region of a glacier terminus, we carried out field measurements on the terminus of Rhonegletscher, Switzerland. This paper reports surface melt rate and albedo measurements from July to September 2009. Both variables varied substantially over the studied area. The field data were compared with a distributed temperature-index melt model to evaluate the ability of the latter to reproduce small-scale melt patterns. The small-scale melt pattern is especially important for Rhonegletscher, which is rapidly thinning under the influence of factors related to proglacial lake formation. The non-uniform melt rates on the surface of the glacier control the evolution of the terminus and future development of the lake.

\section{METHOD}

\section{Study site}

Rhonegletscher is a temperate valley glacier with a length of $9 \mathrm{~km}$ and an area of about $16 \mathrm{~km}^{2}$ in 2007 (Fig. 1a; Bauder and others, 2007). Having retreated $1700 \mathrm{~m}$ from 1878 to 2000, the glacier terminus is now at the top of a steep cliff (Sugiyama and others, 2007). Because the current terminus is located over a depression in the bedrock, a new proglacial lake formed in 2005. The impact of this lake on the glacier is drawing intense glaciological and public attention. The terminus of the glacier is thinning at an increasing rate (Sugiyama and others, 2008) as a result of rising air 

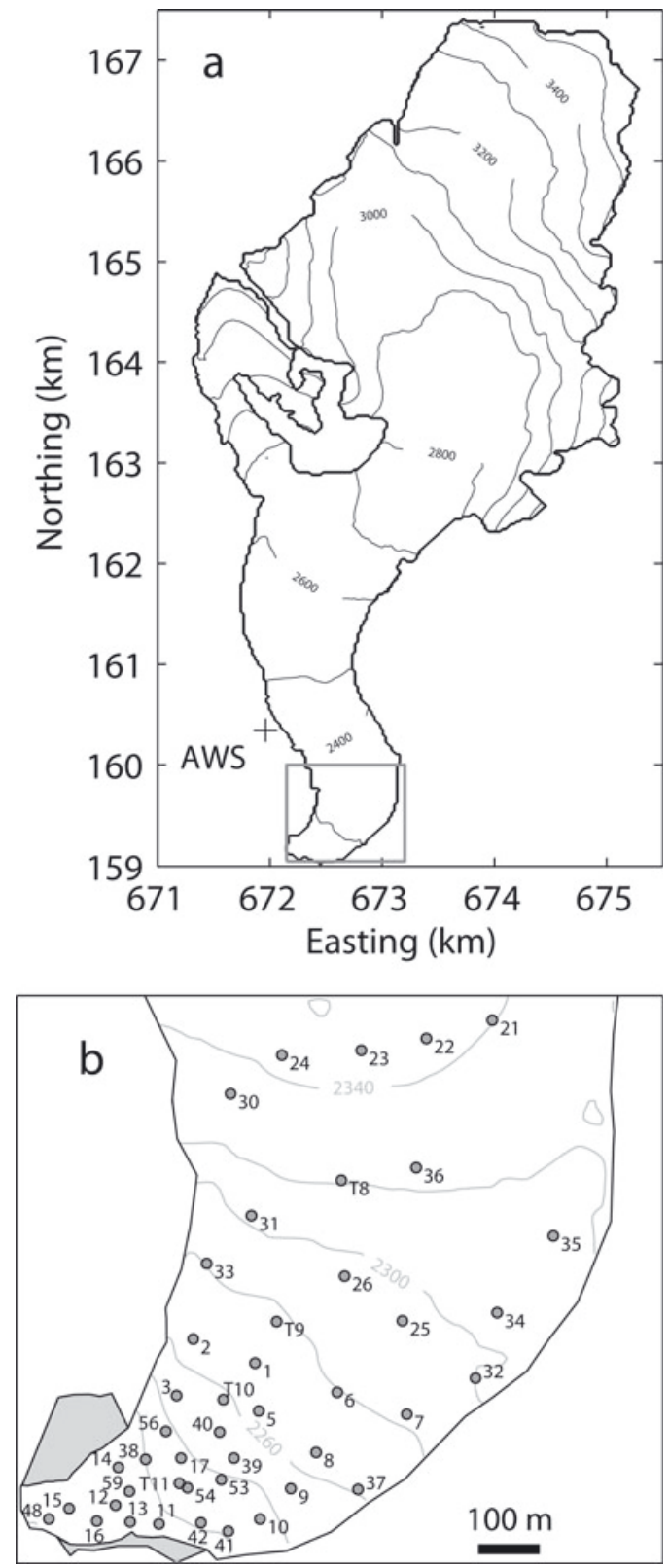

Fig. 1. (a) Map of Rhonegletscher with surface contour lines at $100 \mathrm{~m}$ intervals. The location of the automatic weather station (AWS) is indicated by a cross. (b) The study site indicated by the box in (a). The locations of ablation stakes are indicated by filled circles. The contour lines show surface elevation at intervals of $20 \mathrm{~m}$. The two proglacial lakes are indicated by the shaded areas. The coordinates correspond to the official Swiss coordinate system.

temperature, elevated ice-flow speed (Tsutaki and others, 2011) and rapid ice dissipation by melting and fragmentation into the lake. Our study site is the region extending approximately $1 \mathrm{~km}$ upstream of the glacier from the terminus (Fig. 1b).

\section{Surface melt measurements}

The surface melt rate was measured by inserting aluminium ablation stakes $2-4 \mathrm{~m}$ in length into the glacier (see Fig. $1 \mathrm{~b}$ for the stake locations). We installed 44 stakes in July 2009 and monitored their lengths above the surface every 1-10 days. The stakes were redrilled before they melted out. The mean melt rate was calculated over the entire study period from 6 July to 6 September 2009. Because of ice surface roughness and tilt of the stakes, the precision of individual readings was $10-30 \mathrm{~mm}$. Because the reading error accumulates when the stakes were redrilled, the accuracy in the total melt was about $100 \mathrm{~mm}$. The total melt over the study period in the region was $>2 \mathrm{~m}$ in ice thickness; thus, the error in the mean melt rate was $<5 \%$. The readings were converted to water equivalent (w.e.) by assuming the density of ice to be $900 \mathrm{~kg} \mathrm{~m}^{-3}$.

\section{Albedo measurements}

The surface albedo was measured between 1100 and $1600 \mathrm{~h}$ on 5 August 2009 in the vicinity of the ablation stakes. The cloud cover on that day was $<10 \%$ according to visual observation. The upward and downward radiation energies were measured with an albedo meter (EKO Instruments MR21) and recorded with a datalogger (Hioki 3645). The albedo meter was held $1 \mathrm{~m}$ from the ice surface, and the radiation was measured for at least $1 \mathrm{~min}$. The albedo was computed from the radiation energies and incident angle of the solar radiation following the standard procedure (Jonsell and others, 2003; Dewalle and Rango, 2008). The fluctuation in the radiation energies during the $1 \mathrm{~min}$ measurement period was $<5 \%(1-2 \%$ in general), and the standard deviation in the downward radiation energy over the entire survey period was $4.5 \%$.

\section{Meteorological observations}

Meteorological observations were carried out on the western flank of the glacier at 2531 ma.s.l. (Fig. 1a) using an automatic weather station (Vaisala WXT510), installed at a height of $1.8 \mathrm{~m}$ from a rock surface, that measured air temperature, precipitation, humidity and wind speed. Sensors measured these variables at $10 \mathrm{~s}$ intervals; mean values were recorded every $5 \mathrm{~min}$ with a datalogger (Campbell CR1000).

\section{Melt model}

We used the following numerical model to compute twodimensional (2-D) snow and ice melt-rate $\left(M\left(\mathrm{mw}\right.\right.$.e. $\left.\left.\mathrm{d}^{-1}\right)\right)$ distributions over the study period on a regular grid of $25 \times 25 \mathrm{~m}$ :

$$
M=\left\{\begin{array}{ll}
\left(f_{\mathcal{M}}+r_{\mathrm{s} / \mathrm{i}} l\right) T_{\mathrm{m}} & T_{\mathrm{m}}>0 \\
0 & T_{\mathrm{m}} \leq 0
\end{array},\right.
$$

where $f_{M}$ is a melt factor (mw.e. $\left.\mathrm{d}^{-1}{ }^{\circ} \mathrm{C}^{-1}\right), r_{\mathrm{s}}$ and $r_{\mathrm{i}}$ are radiation factors for snow and ice surfaces $\left(\mathrm{m}^{3} \mathrm{~W}^{-1} \mathrm{~d}^{-1}{ }^{\circ} \mathrm{C}^{-1}\right), l$ is the daily total potential solar radiation $\left(\mathrm{W} \mathrm{m}^{-2}\right)$ and $T_{\mathrm{m}}$ is daily mean temperature $\left({ }^{\circ} \mathrm{C}\right)$. The temperature at the elevation of the gridcell is calculated from the weather station data using a lapse rate of $\mathrm{d} T / \mathrm{d} z$. The snow/ice surface condition is distinguished by monitoring snow depth computed from modelled snowmelt and solid precipitation. The above model is based on the distributed temperature-index model reported by Hock (1999; see also Huss and others, 2008a). The dependence of radiation efficiency on surface inclination and shading by surrounding topography is quantified by computing I for each gridpoint from the incident angle of solar radiation and a digital elevation model (DEM), as described by Hock (1999). In the case of a conventional degree-day model, the second term in Equation (1) can be neglected and the parameter $f_{M}$ is called the 'degree-day factor'.

To apply the model to Rhonegletscher, the parameters $f_{M}$ and $r_{s / i}$ in Equation (1) and $\mathrm{d} T / \mathrm{d} z$ were calibrated so that 


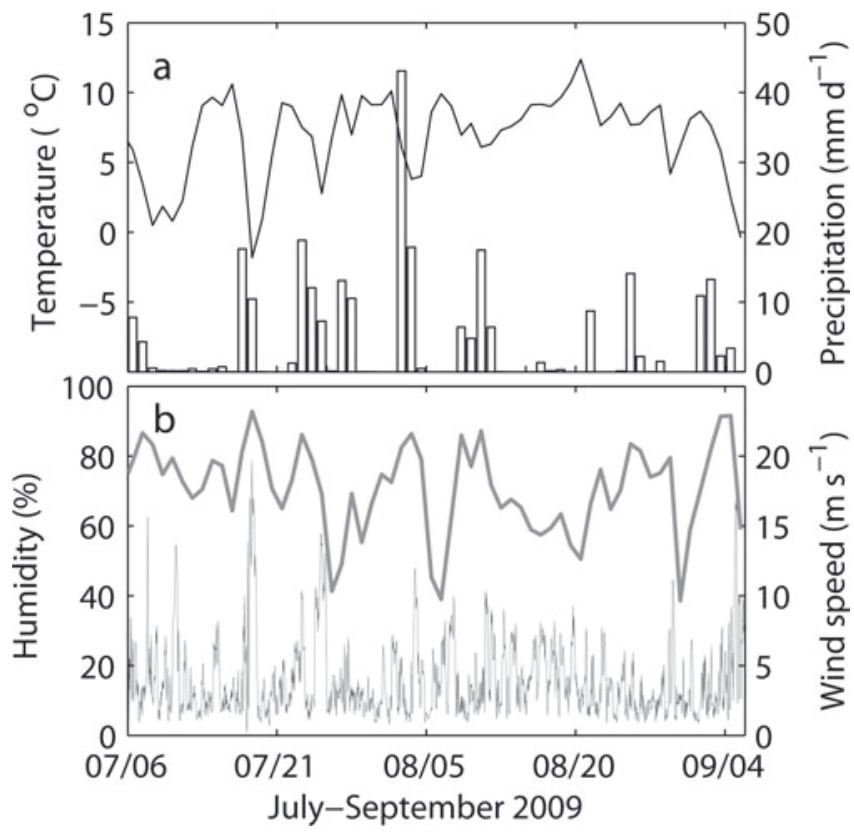

Fig. 2. (a) Daily mean air temperature (curve) and daily precipitation (bars) and (b) daily mean humidity (bold grey) and hourly mean wind speed. Dates are $\mathrm{mm} / \mathrm{dd}$.

(1) the mean misfit of computed total melt with the field data was close to zero and (2) the root-mean-square error was minimized. These parameters were assumed to be constant in space and time. We used a DEM constructed by photogrammetrical evaluation of aerial photographs taken in September 2007 ( $25 \mathrm{~m}$ resolution, $\pm 0.3 \mathrm{~m}$ accuracy) (Bauder and others, 2007). Daily mean air temperatures from the above-mentioned weather station were used to drive the computation.

\section{RESULTS}

\section{Meteorological data}

Meteorological data obtained from 6 July to 6 September 2009 are shown in Figure 2. During the study period, the mean air temperature was $6.9^{\circ} \mathrm{C}$, with a standard deviation of $3.51^{\circ} \mathrm{C}$, the total precipitation was $261.0 \mathrm{~mm}$ and the mean wind speed was $4.0 \mathrm{~m} \mathrm{~s}^{-1}$. There was a snowfall event during 17-18 July, resulting in a $0.05-0.1 \mathrm{~m}$ thick snow cover on the glacier.

\section{Surface melt}

Figure 3a shows a map of the mean melt rate for the period 6 July to 6 September 2009. Ablation stake data are listed in Table 1. The mean melt rate over all measurement sites was $56.1 \mathrm{~mm}$ w.e. $\mathrm{d}^{-1}$, with a standard deviation of $7.5 \mathrm{~mm}$ w.e. $\mathrm{d}^{-1}$. Measurements at the stakes were interpolated in space with cubic spline interpolation to obtain the overall spatial distribution. The 2-D melt pattern shows substantial spatial variation. Over an elevation range of only $100 \mathrm{~m}$, the melt rate varied by a factor of more than two. For example, there is a spot of low melt in the upper reaches of the study area (32.8 $\mathrm{mm}$ w.e. $\mathrm{d}^{-1}$ at stake 23$)$, and the melt rate is generally smaller in the northeast part of the studied area. The greatest melt was observed near the eastern margin at stake 2 $\left(71.9 \mathrm{~mm}\right.$ w.e. $\left.\mathrm{d}^{-1}\right)$. The melt pattern near the terminus is
Table 1. The locations of the ablation stakes, albedos measured on 5 August 2009 , measured $\left(M_{\text {meas }}\right)$ and computed $\left(M_{\text {comp }}\right)$ melt rates from 6 July to 6 September 2009 and deviation of the computed melt rates from the measurements, $\Delta M\left(\left(M_{\text {comp }} / M_{\text {meas }}-1\right) \times 100 \%\right)$; coordinates correspond to the official Swiss coordinate system

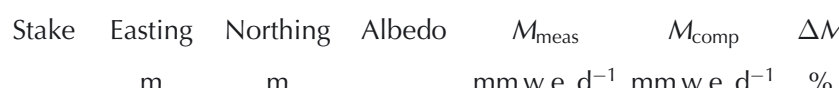

\begin{tabular}{|c|c|c|c|c|c|}
\hline 672538 & 159402 & 0.21 & 58.21 & 55.27 & -5.0 \\
\hline 672437 & 159441 & 0.11 & 71.93 & 54.89 & -23.7 \\
\hline 672410 & 159350 & 0.14 & 60.68 & 54.90 & -9.5 \\
\hline 672544 & 159324 & 0.21 & 59.17 & 58.61 & -0.9 \\
\hline 672671 & 159355 & 0.25 & 54.07 & 55.84 & 3.3 \\
\hline 672784 & 159319 & 0.11 & 56.18 & 56.19 & 0.0 \\
\hline 672637 & 159257 & 0.10 & 59.44 & 57.21 & -3.8 \\
\hline 672596 & 159198 & 0.17 & 64.02 & 58.37 & -8.8 \\
\hline 672546 & 159149 & 0.13 & 54.94 & 60.34 & 9.8 \\
\hline 672382 & 159141 & 0.09 & 55.02 & 62.50 & 13.6 \\
\hline 672311 & 159171 & 0.11 & 45.87 & 59.65 & 30.0 \\
\hline 672335 & 159144 & 0.06 & 60.56 & 59.97 & -1.0 \\
\hline 672316 & 159233 & 0.09 & 67.43 & 55.79 & -17.3 \\
\hline 672236 & 159166 & 0.08 & 52.33 & 56.00 & 7.0 \\
\hline 672281 & 159145 & 0.06 & 61.80 & 59.37 & -3.9 \\
\hline 672418 & 159248 & 0.17 & 60.31 & 58.85 & -2.4 \\
\hline 672923 & 159960 & 0.24 & 46.74 & 49.66 & 6.2 \\
\hline 672816 & 159930 & 0.30 & 44.27 & 50.58 & 14.2 \\
\hline 672710 & 159911 & 0.33 & 32.81 & 51.08 & 55.7 \\
\hline 672581 & 159903 & 0.24 & 53.27 & 52.06 & -2.3 \\
\hline 672777 & 159471 & 0.22 & 49.06 & 53.53 & 9.1 \\
\hline 672683 & 159544 & 0.27 & 53.13 & 54.55 & 2.7 \\
\hline 672498 & 159840 & 0.13 & 52.40 & 53.32 & 1.8 \\
\hline 672532 & 159642 & 0.16 & 55.05 & 55.24 & 0.4 \\
\hline 672896 & 159378 & 0.09 & 59.69 & 53.34 & -10.6 \\
\hline 672459 & 159564 & 0.13 & 64.35 & 54.55 & -15.2 \\
\hline 672931 & 159484 & 0.12 & 40.73 & 51.65 & 26.8 \\
\hline 673022 & 159609 & 0.10 & 50.01 & 50.61 & 1.2 \\
\hline 672799 & 159720 & 0.26 & 47.90 & 53.37 & 11.4 \\
\hline 672705 & 159197 & 0.09 & 57.70 & 53.58 & -7.1 \\
\hline 672360 & 159246 & 0.13 & 62.52 & 56.56 & -9.5 \\
\hline 672503 & 159248 & 0.19 & 62.38 & 60.15 & -3.6 \\
\hline 672480 & 159290 & 0.16 & 62.71 & 58.79 & -6.3 \\
\hline 672494 & 159129 & 0.10 & 55.86 & 60.98 & 9.2 \\
\hline 672450 & 159143 & 0.12 & 59.30 & 62.65 & 5.6 \\
\hline 672203 & 159149 & 0.11 & 54.58 & 53.27 & -2.4 \\
\hline 672483 & 159213 & 0.20 & 46.79 & 60.37 & 29.0 \\
\hline 672428 & 159200 & 0.16 & 62.20 & 59.61 & -4.2 \\
\hline 672393 & 159291 & 0.12 & 60.82 & 55.69 & -8.4 \\
\hline 672334 & 159194 & 0.13 & 53.93 & 57.19 & 6.1 \\
\hline 672678 & 159700 & 0.21 & 58.50 & 54.26 & -7.3 \\
\hline 672573 & 159470 & 0.24 & 59.23 & 55.42 & -6.4 \\
\hline 672486 & 159343 & 0.11 & 53.49 & 57.63 & 7.7 \\
\hline 672415 & 159207 & 0.08 & 68.59 & 58.95 & -14.1 \\
\hline
\end{tabular}

spatially complex. In general, the melt rate increases downglacier and from the glacier centre to the margins (Fig. 3a).

The spatial pattern of the melt rate was analysed by computing semivariance:

$$
\gamma(h)=\frac{1}{N(h)} \sum_{N(h)}\left\{M\left(\mathbf{x}_{i}\right)-M\left(\mathbf{x}_{j}\right)\right\}^{2},
$$

where $\mathbf{x}_{i}$ is the $i$ th stake location and $h$ is the so-called lagged distance. The sum is taken over $N(h) \equiv\left\{(i, j): h-50 \mathrm{~m}<\left|\mathbf{x}_{i}-\mathbf{x}_{j}\right|<h+50 \mathrm{~m}\right\}$ (e.g. Cressie, 

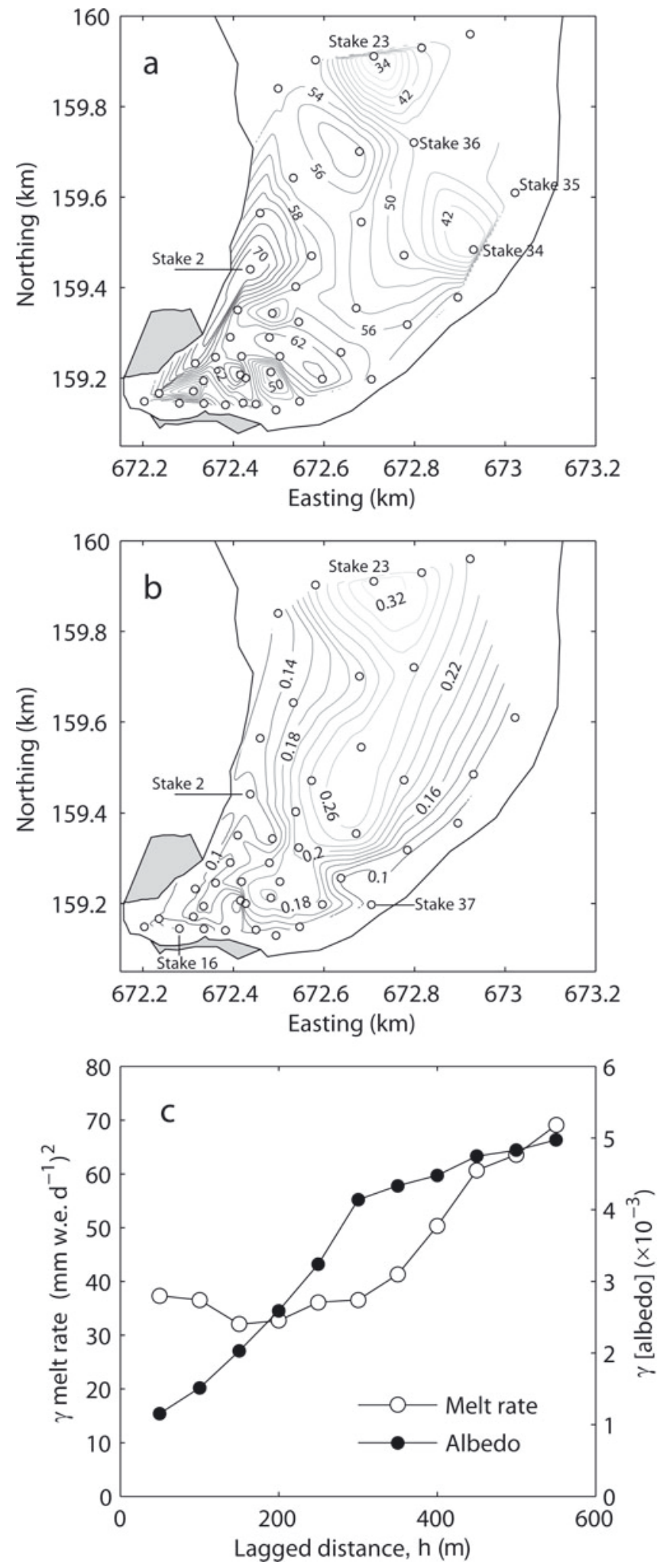

Fig. 3. (a) Mean daily melt rates from 6 July to 6 September 2009 in $\mathrm{mm}$ w.e. $\mathrm{d}^{-1}$. The contour intervals are $2 \mathrm{mmw}$.e. $\mathrm{d}^{-1}$. The locations of ablation stakes are indicated by circles. (b) Surface albedos measured on 5 August 2009. The contour intervals are 0.02. (c) Semivariance computed for the observed melt rate (o) and albedo $(\bullet)$ variations. The tolerance in the lagged distance is $\pm 50 \mathrm{~m}$.

1993). The semivariance, $\gamma(h)$, represents the measure of variance between the data separated by the lagged distance. For example, a low $\gamma(h)$ value indicates that a pair of observations are similar to each other when the distance between the measurement sites is approximately $h$. A plot of semivariance against the lagged distance is referred to as a semivariogram, which demonstrates the similarity between observations as a function of the distance between the data (Fig. 3c). The semivariance is relatively large in the distance range $h<200 \mathrm{~m}$, showing relatively high local variability in the melt rate. Its increase at $h \sim 400 \mathrm{~m}$ indicates that the correlation rapidly decreases at this distance.

\begin{abstract}
Albedo
Figure $3 b$ shows the 2-D distribution of surface albedo measured on 5 August 2009. Individual measurements are listed in Table 1. The albedo clearly decreases from the centre to the margins and down-glacier towards the terminus. The highest albedo, 0.33, was observed in the upper reaches at stake 23. The albedo drops below 0.2 in the area below stakes 2, 5, 8 and 37. The lowest observed value was 0.06 , on a debris-covered surface near the terminus at stakes 13 and 16. These albedos on Rhonegletscher are similar to those measured near the terminus of other mountain glaciers. Brock and others (2000) reported a value of approximately 0.1 at the terminus of Haut Glacier d'Arolla, Switzerland, whereas Klok and others (2003) reported approximately 0.2 at Morteratschgletscher, Switzerland. Jonsell and others (2003) measured 0.06 as the lowest albedo in Storglaciären, Sweden, at a sediment-covered site near the margin.

The semivariogram of the albedo shows features different from that of the melt rate (Fig. 3c). The semivariance is small at short lagged distances, indicating that the albedo values are similar when they are compared within a small scale. It progressively increases within the range $0<h<300 \mathrm{~m}$, which implies the albedo is spatially uncorrelated in the region beyond $300 \mathrm{~m}$.
\end{abstract}

\section{Model results}

The model was calibrated to reproduce the observations from 6 July to 6 September 2009. The best-fitting parameter values were $f_{M}=1.50 \times 10^{-4} \mathrm{~m}$ w.e. $\mathrm{d}^{-1}{ }^{\circ} \mathrm{C}^{-1}, r_{\mathrm{s}}=1.32$ $\times 10^{-5} \mathrm{~m}^{3} \mathrm{~W}^{-1} \mathrm{~d}^{-1}{ }^{\circ} \mathrm{C}^{-1}, r_{\mathrm{i}}=2.20 \times 10^{-5} \mathrm{~m}^{3} \mathrm{~W}^{-1} \mathrm{~d}^{-1}{ }^{\circ} \mathrm{C}^{-1}$ and $\mathrm{d} T / \mathrm{d} z=-9.0 \times 10^{-3}{ }^{\circ} \mathrm{Cm}^{-1}$. Figure 4 compares the computed melt rates at mesh gridpoints with the data obtained at the ablation stakes (see also Table 1). The mean difference between the measured and computed melt rates was $-0.03 \mathrm{~mm}$ w.e. $\mathrm{d}^{-1}$, and the root-mean-square error was $6.7 \mathrm{~mm}$ w.e. $\mathrm{d}^{-1}$. The computed melt pattern reproduces several important features of the observational data (Fig. 5a): the melt rate increases down-glacier and there is a low-melt region in the northeast part. Nevertheless, the model predicts weaker spatial variations overall, that is, the high and low melt rates are under- and overestimated, respectively. The discrepancy reaches $-24 \%$ and $+56 \%$ at stakes 2 and 23, respectively (Fig. 5b; Table 1). Moreover, the calculated melt rate near the terminus increases from north to south, contrary to the observations.

\section{DISCUSSION}

Our measurements revealed a complex spatial melt pattern over the terminus of Rhonegletscher. The mean melt rate during the observation period at stake 2 was more than double that at stake 23 . The melt rate generally increases down-glacier, but the spatial variations cannot be explained by surface elevation alone. Degree-day factors (DDFs) were 


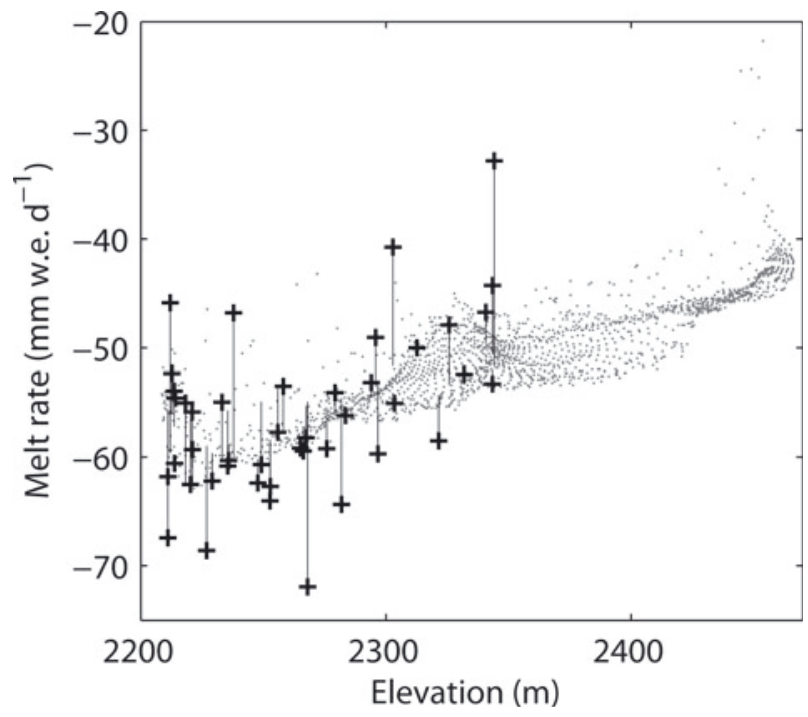

Fig. 4. Total surface melt from 6 July to 6 September 2009 computed using a melt model for all mesh gridpoints (.) and measured in the field at the stakes (+). The length of the vertical lines indicates the difference between the measured and computed melt at the stake locations.

calculated for every ablation stake by linear regression of cumulative melt on the sum of positive degree-days over the entire study period. Measured air temperature was extrapolated to the stake elevation using a lapse rate of $6.5 \times 10^{-3}{ }^{\circ} \mathrm{C} \mathrm{m}^{-1}$. DDFs vary from $5.2 \mathrm{~mm}$ w.e. $\mathrm{d}^{-1}{ }^{\circ} \mathrm{C}^{-1}$ to $11.2 \mathrm{~mm}$ w.e. $\mathrm{d}^{-1}{ }^{\circ} \mathrm{C}^{-1}$ for stakes 23 and 2, respectively. These values are within the range of previously reported DDFs on ice surfaces (Braithwaite and Zhang, 2000; Hock, 2003), but the extent of the spatial variation is greater than those obtained for other glaciers (Hock, 2003).

One of the reasons for this spatial variation is the surface albedo. The melt rate was small at stake 23 because the albedo was high, as shown in Figure $3 \mathrm{a}$ and $\mathrm{b}$. The complex melt pattern near the terminus also corresponds to the albedo pattern. For example, the low albedo at stake T11 and high albedo at stake 53 coincide with large and small melt rates, respectively. The albedo was lower near the glacier margins, consistent with the trend in melt rate, because ice was contaminated by dark particles related to the emergence of basal ice and the surface was covered with more debris. A scatter plot of DDFs versus albedo at each ablation stake demonstrates the important influence of albedo on the melt rate (Fig. 6a). A linear regression of the data yields a relationship between the DDF and albedo, $\alpha$, of: $\mathrm{DDF}=-8.2 \alpha+10.2$, with a correlation coefficient of $r=-0.49$ and a $p$-value of 0.0006 (the probability of obtaining $|r|>0.49$ assuming the true correlation is zero). Below the line connecting stakes 2, 5, 8 and 37, the albedo dropped and the melt rate increased. In this region, the decrease in albedo seems to be related to the presence of crevasses. Meltwater washed away surface particles in the smooth upper reaches, but surface water flow was impeded in the heavily crevassed lower reaches (Fig. 7a). It should also be noted that the crevassed surface traps more solar radiation than a flat surface, which increases net energy absorption in the region (Pfeffer and Bretherton, 1987).

The observed melt pattern cannot be explained with only albedo variations, as implied by the different spatial
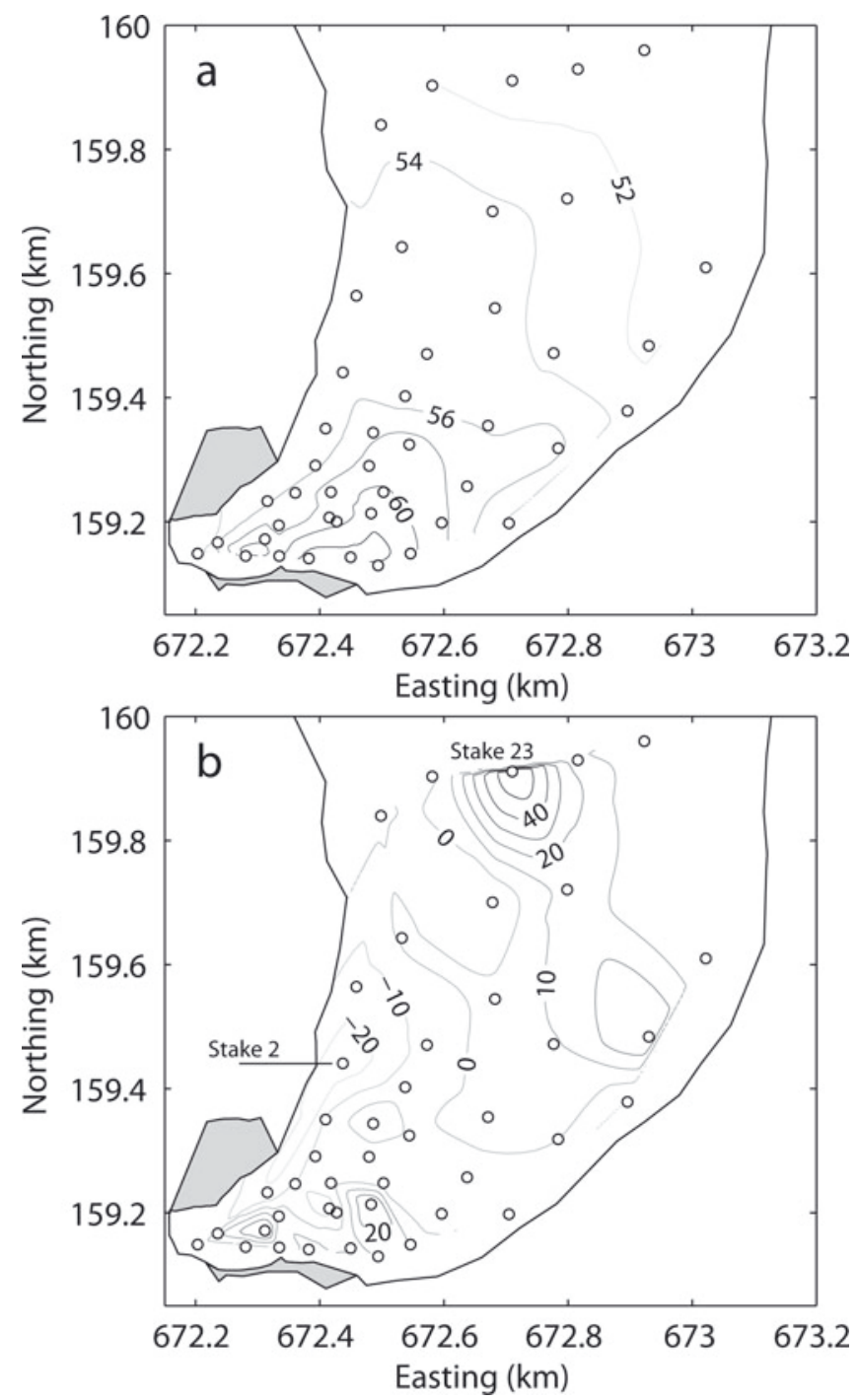

Fig. 5. (a) Melt rates ( $\mathrm{mm}$ w.e. $\mathrm{d}^{-1}$ ) computed for the period 6 July to 6 September 2009; and (b) relative deviations from the observed values, $\left(M_{\text {comp }} / M_{\text {meas }}-1\right) \times 100 \%$. The locations of ablation stakes are indicated by circles.

statistical features obtained by the semivariance analysis (Fig. 3c). Another important effect is shading by the surrounding topography. A side-wall to the southeast of the glacier terminus shaded the eastern side of the study area for several hours each morning (Fig. 7b). The low-melt-rate region around stakes 34 and 35 coincides with this area of low potential radiation (Fig. 3a). This effect is taken into account by the potential solar radiation term in the model and is clearly recognizable in Figure 8 . The reduced melt rate was therefore reproduced by the computed melt pattern, although its magnitude was smaller than the observation. Correlation of the DDF to the absorbed potential radiation $(I(1-\alpha))$ is more significant (Fig. 6b; $r=0.55$ and $p=0.0001)$ than the correlation of the DDF to the albedo.

The very strong melt observed at stake 2 is difficult to explain. Albedo increased towards the margins, but the melt rate was greater near the western margin than on the other side of the glacier. Seasonal variation in albedo is often important in the ablation area (e.g. Brock and others, 2000), but no significant change in surface conditions was recognized in this region over the study period. The surface 

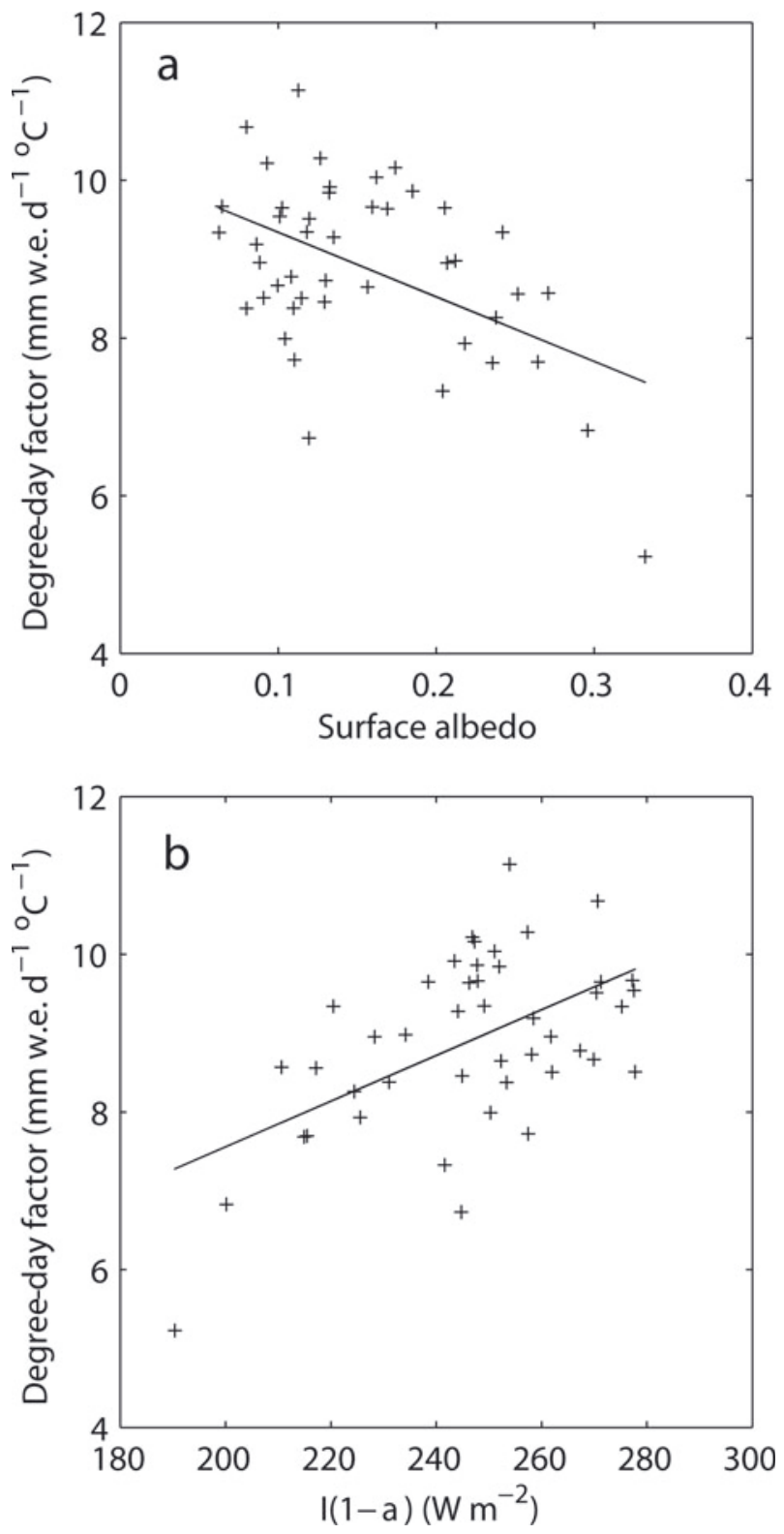

Fig. 6. (a) DDFs and surface albedos and (b) DDFs and absorbed potential solar radiation, $I(1-\alpha)$, obtained at the ablation stakes. The lines are linear regressions of the data.

was steeply inclined towards the south in the western part of the glacier, but the model, which includes the incident angle of solar radiation, does not produce a similar pattern. We speculate that the increase in melt rate arises from the absorption of longwave radiation emitted by the bare bedrock on the western flank, which has been exposed by the retreat of the glacier in this region (Fig. 7c). A similar effect has been observed at Franz Josef Glacier, New Zealand (Ishikawa and others, 1992).

Comparing the field data to the computed results confirms the ability of the distributed temperature-index model to include the effects of potential solar radiation. However, several important features in the spatial melt distribution were insufficiently captured. It is clear from the observation at stake 23, for example, that variations in ice albedo are one of the most influential factors not included in the model. Albedo can be included as an additional model parameter (e.g. Pellicciotti and others, 2005); however, our measurements show that its spatial variation is large and
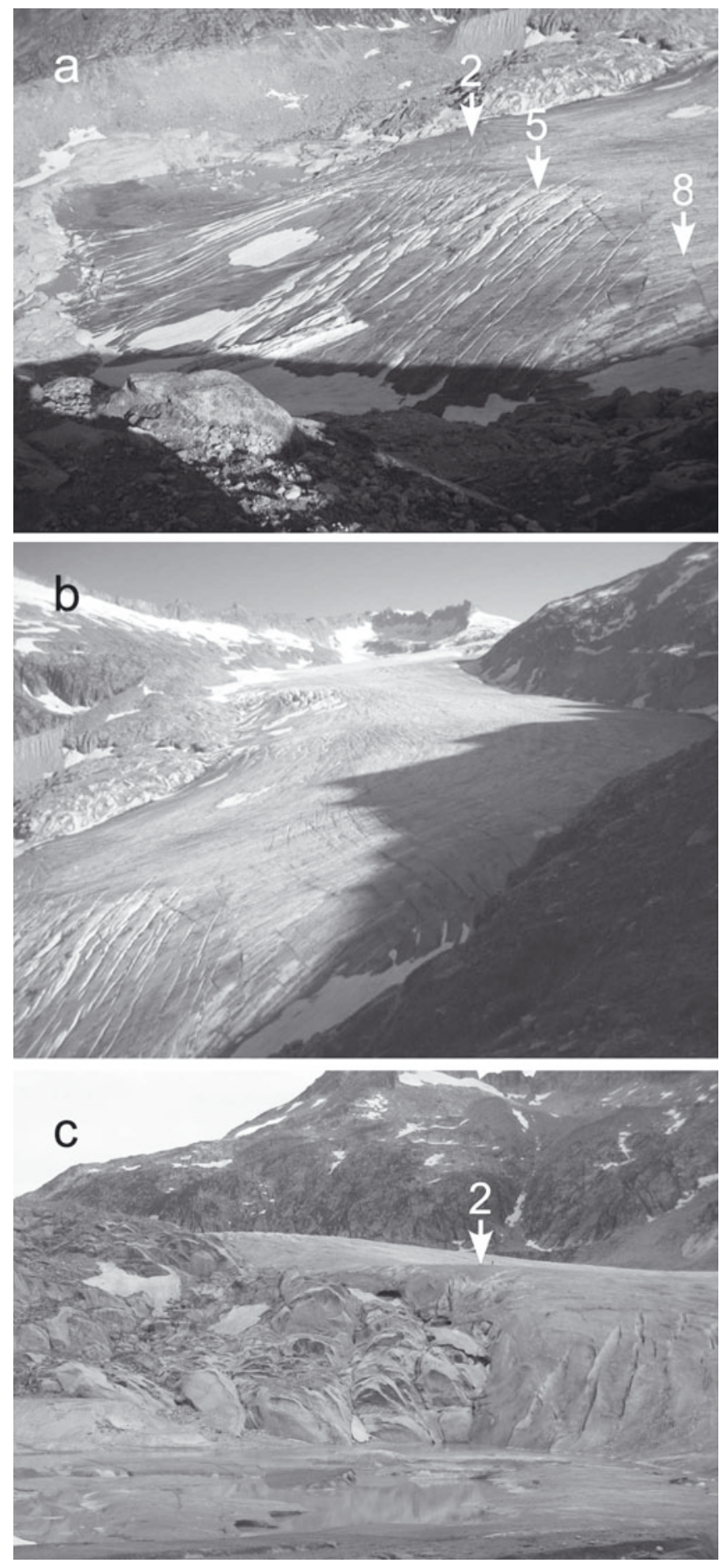

Fig. 7. Photographs showing (a) the lower part of the study area from the southeast, (b) the upper part of the study area from the south and (c) the western margin of the glacier from the southwest. The approximate locations of the ablation stakes are indicated. The photographs were taken on (a) 16 July 2009, (b) 16 July 2009 at $0844 \mathrm{~h}$ and (c) 26 July 2008.

does not follow a predictable pattern (Fig. 3b). This implies that albedo would have to be measured over the glacier, which is often not feasible. To compute an accurate estimate of total meltwater production in a region, simple temperature-index models should not be calibrated on singleablation-stake data; the data may be influenced by high small-scale variations in melt rate, as demonstrated by our measurements. 


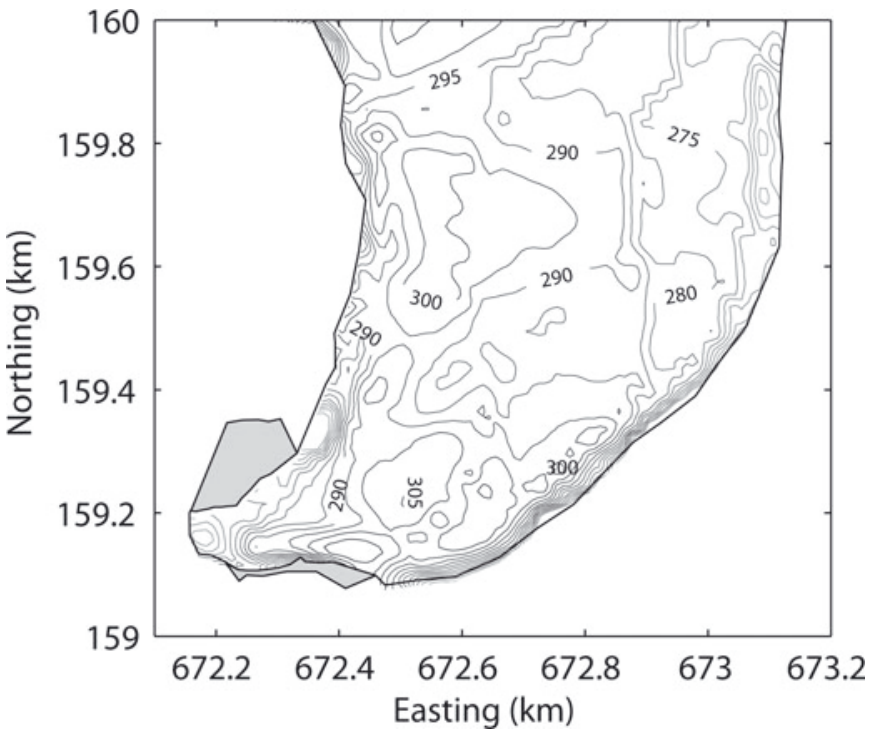

Fig. 8. Potential solar radiation computed for 29 July $2009\left(\mathrm{~W} \mathrm{~m}^{-2}\right)$. The contour intervals are $5 \mathrm{~W} \mathrm{~m}^{-2}$.

\section{CONCLUSION}

We measured glacier surface melt in the terminus of Rhonegletscher at a resolution of $20-100 \mathrm{~m}$. The surface melt rate obtained at 44 stakes over the summer of 2009 showed significant spatial variability. The DDFs obtained from the measured melt at the stakes over a 2 month period ranged from 5.2 to $11.2 \mathrm{~mm}$ w.e. $\mathrm{d}^{-1}{ }^{\circ} \mathrm{C}^{-1}$ within an area extending $1 \mathrm{~km}$ from the glacier terminus. Part of the variation can be plausibly explained by differences in surface albedo. Our measurements of albedo range from 0.06 to 0.33 , and the highest albedo coincided with low melt rate. The albedo generally decreased from the glacier centre to the margins, in agreement with the observed melt rate variations. The influence of shading by surrounding topography is evident from the field data. The melt rate decreased in the northeast part of the study site, where the potential solar radiation was smaller due to shading by mountain ridges to the east of the glacier. However, some features of the 2-D melt pattern are still difficult to explain. The greatest melt rate was observed near the western margin. Radiation from rock walls close to the glacier is a possible source of the heat energy.

We computed melt rates over the glacier surface using a distributed temperature-index melt model. The model was calibrated using the field data, and the computed spatial melt pattern was compared to observations. The model successfully reproduced the decrease in melt rate due to the shading. Geometrical effects can therefore be taken into account by the model. The model results deviate from the observations by $+56 \%$ and $-24 \%$ at the lowest and highest melt rates, respectively. Care should therefore be taken when using such models to investigate a spatial melt pattern at high resolution. Model calibration should be carried out with data sampled in a wide range of ice-surface albedo and other conditions in order to obtain accurate total melt.

\section{ACKNOWLEDGEMENTS}

We thank M. Funk, A. Bauder and members of the Rhonegletscher field campaign in 2009 for their help in the field.
Materials for the field campaign were loaned by the Section of Glaciology, Swiss Federal Institute of Technology (VAW), ETH Zürich. The manuscript was substantially improved by constructive review comments provided by two anonymous referees and the scientific editor, D. MacAyeal. This research was funded by the Japanese Ministry of Education, Science, Sports and Culture, Grant-in-Aid, 20540418, 2008-10 and the Global Center of Excellence Program, MEXT, Japan.

\section{REFERENCES}

Arnold, N.S., W.G. Rees, A.J. Hodson and J. Kohler. 2006. Topographic controls on the surface energy balance of a high Arctic valley glacier. J. Geophys. Res., 111(F2), F02011. (10.1029/2005JF000426.)

Bauder, A., M. Funk and M. Huss. 2007. Ice-volume changes of selected glaciers in the Swiss Alps since the end of the 19th century. Ann. Glaciol., 46, 145-149.

Braithwaite, R.J. 1995. Positive degree-day factors for ablation on the Greenland ice sheet studied by energy-balance modelling. J. Glaciol., 41(137), 153-160.

Braithwaite, R.J. and Y. Zhang. 2000. Sensitivity of mass balance of five Swiss glaciers to temperature changes assessed by tuning a degree-day model. J. Glaciol., 46(152), 7-14.

Brock, B.W., I.C. Willis and M.J. Sharp. 2000. Measurement and parameterization of albedo variations at Haut Glacier d'Arolla, Switzerland. J. Glaciol., 46(155), 675-688.

Cressie, N.A.C. 1993. Statistics for spatial data. New York, etc., John Wiley and Sons.

DeWalle, D.R. and A. Rango. 2008. Principles of snow hydrology. Cambridge, etc., Cambridge University Press.

Hock, R. 1999. A distributed temperature-index ice- and snowmelt model including potential direct solar radiation. J. Glaciol., 45(149), 101-111.

Hock, R. 2003. Temperature index melt modelling in mountain areas. J. Hydrol., 282(1-4), 104-115.

Hock, R. and B. Holmgren. 2005. A distributed surface energybalance model for complex topography and its application to Storglaciären, Sweden. J. Glaciol., 51(172), 25-36.

Huss, M., A. Bauder, M. Funk and R. Hock. 2008a. Determination of the seasonal mass balance of four Alpine glaciers since 1865 . J. Geophys. Res., 113(F1), F01015. (10.1029/2007JF000803.)

Huss, M., D. Farinotti, A. Bauder and M. Funk. 2008b. Modelling runoff from highly glacierized alpine drainage basins in a changing climate. Hydrol. Process., 22(19), 3888-3902.

Huss, M., M. Funk and A. Ohmura. 2009. Strong Alpine glacier melt in the 1940s due to enhanced solar radiation. Geophys. Res. Lett., 36(23), L23501. (10.1029/2009GL040789.)

Ishikawa, N., I.F. Owens and A.P. Sturman. 1992. Heat balance characteristics during fine periods on the lower part of the Franz Josef Glacier, South Westland, New Zealand. Int. J. Climatol., 12(4), 397-410.

Jonsell, U., R. Hock and B. Holmgren. 2003. Spatial and temporal variations in albedo on Storglaciären, Sweden. J. Glaciol., 49(164), 59-68.

Klok, E.J. and J. Oerlemans. 2002. Model study of the spatial distribution of the energy and mass balance of Morteratschgletscher, Switzerland. J. Glaciol., 48(163), 505518.

Klok, E.J., W. Greuell and J. Oerlemans. 2003. Temporal and spatial variation of the surface albedo of Morteratschgletscher, Switzerland, as derived from 12 Landsat images. J. Glaciol., 49(167), 491-502.

Meier, M.F. and 7 others. 2007. Glaciers dominate eustatic sealevel rise in the 21st century. Science, 317(5841), 1064-1067.

Oerlemans, J., R.H. Giesen and M.R. van den Broeke. 2009. Retreating alpine glaciers: increased melt rates due to accumulation of dust (Vadret da Morterastch, Switzerland). J. Glaciol., 55(192), 729-736. 
Ohmura, A. 2001. Physical basis for the temperature-based meltindex method. J. Appl. Meteorol., 40(4), 753-761.

Pellicciotti, F., B.W. Brock, U. Strasser, P. Burlando, M. Funk and J.G. Corripio. 2005. An enhanced temperature-index glacier melt model including shortwave radiation balance: development and testing for Haut Glacier d'Arolla, Switzerland. J. Glaciol., 51(175), 573-587.

Pfeffer, W.T. and C.S. Bretherton. 1987. The effect of crevasses on the solar heating of a glacier surface. IAHS Publ. 170 (Symposium at Vancouver 1987 - The Physical Basis of Ice Sheet Modelling), 191-205.

Schaefli, B., B. Hingray and A. Musy. 2007. Climate change and hydropower production in the Swiss Alps: quantification of potential impacts and related modelling uncertainties. Hydrol. Earth Syst. Sci., 11(3), 1191-1205.
Shea, J.M., R.D. Moore and K. Stahl. 2009. Derivation of melt factors from glacier mass-balance records in western Canada. J. Glaciol., 55(189), 123-130.

Sugiyama, S., A. Bauder, C. Zahno and M. Funk. 2007. Evolution of Rhonegletscher, Switzerland, over the past 125 years and in the future: application of an improved flowline model. Ann. Glaciol., 46, 268-274.

Sugiyama, S., S. Tsutaki, D. Nishimura, H. Blatter, A. Bauder and M. Funk. 2008. Hot water drilling and glaciological observations at the terminal part of Rhonegletscher, Switzerland in 2007. Bull. Glaciol. Res., 26, 41-47.

Tsutaki, S., D. Nishimura and S. Sugiyama. 2011. Changes in glacier dynamics under the influence of proglacial lake formation in Rhonegletscher, Switzerland. Ann. Glaciol., 52(58) (see paper in this issue). 